\title{
Pemberdayaan Yatim Berdasarkan Nilai-Nilai Al-Qur'an Dalam Pengelolaan Panti Asuhan Pimpinan Daerah Muhammadiyah Kabupaten Pamekasan
}

\author{
Hendri Masduki \\ Sekolah Tinggi Agama Islam Al Falah (STAIFA) Pamekasan \\ Habibah Masduki \\ Program Sarjana (S-1) Fakultas Ilmu Sosial dan Ilmu Politik Program Studi Sosiologi \\ Universitas Muhammadiyah Malang \\ hendri.pgri@gmail.com
}

\begin{abstract}
Abstrak
Al-Qur'an mempunyai perhatian yang sangat khusus terhadap anak yatim. Perhatian Al-Qur'an terhadap anak yatim ini telah muncul sejak masa awal turunnya wahyu sampai pada masa akhir di saat-saat wahyu tersebut lengkap dan sempurna. Perhatian terhadap anak Yatim, tidak hanya dilakukan institusi Negara, akan tetapi juga dilakukan oleh organisasi kemasyarakatan yang secara kelembagaan berbentuk panti asuhan, yang mempunyai misi mulia dalam kerangka pemberdayaan anak Yatim, sebagai refleksi terhadap amanah terbesar Al-Qur'an dan Islam kepada kaum muslimin. Berangkat dari pemikiran ini maka judul dalam penelitian ini adalah: "Pemberdayaan Yatim Berdasarkan Nilai-Nilai Al-Qur'an Dalam Pengelolaan Panti Asuhan Pimpinan Daerah Muhammadiyah Kabupaten Pamekasan". Penelitian ini termasuk penelitian Lapangan (field reasearch), dengan metode kualitatif. Metode kualitatif, adalah suatu penelitian yang tidak mempersoalkan hubungan variabel dalam penelitian, dan tidak tigunakan operasi hitung matematika, dan atau angka-angka. Metode kualitatif, adalah suatu metode yang bertujauan untuk menggambarkan secara naratif tentang temuan-temuan penelitian dilapangan, yang selanjutnya penelitian ini disebut penelitian deskriptif kualitatif. Dalam proses pengumpulan data, peneliti menggunakan wawancara (interview) dan observasi sebagai data pokok atau data primer. Sedangkan untuk mendapatkan data sekunder atau penunjang, peneliti menggunakan teknik dokumentasi. Analisis dalam penelitian ini adalah analis deskriptif, model interaktif Miles and Huberman yang terdiri dari: pengumpulan data, reduksi data, penyajian data, dan penarikan kesimpulan. Dan selanjutnya dilakukan pengujian keabsahan data, dengan menggunakan teknik triangulasi. Triangulasi data adalah suatu metode dengan cara membandingkan data-data yang terkumpul dari berbagai teknik yang berbeda. Hasil dalam penelitian ini menunjukkan bahwa Pertama, Pemberdayaan Yatim adalah proses pengabdian spiritualitas Keagamaan untuk menjalankan risalah Al-Qur'an, guna untuk memperoleh Ridla Allah SWT; Kedua, Pemberdayaan Yatim adalah proses pemenuhan kebutuhan kepada Yatim yang sejatinya butuh pengayoman, baik secara jasmaniyah maupun secara batiniyah; dan Ketiga Pemberdayaan Yatim
\end{abstract}


adalah proses penyelamatan terhadap harta Yatim sebagai tanggung jawab spiritual dan sosial.

Kata Kunci : Pemberdayaan Yatim, Nilai-nilai Al-Qur'an, Pengelolaan Panti Asuhan; Pimpinan Daerah Muhammadiyah Pamekasan. 


\section{Pendahuluan}

Islam memandang bahwa manusia adalah entitas riil yang sangat kompleks dan dimensional. kompleksitas dan dimensionalitas keberadaan manusia itu sendiri menjadi alasan utama, bahwa manusia merupakan titik sentral dan sasaran utama dalam menanamkan nilai-nilai spiritulitas agar manusia betul-betul menjadi manusia yang hakiki. Nilai-nilai spiritualitas yang ditawarkan Islam dalam kerangka memanusiakan manusia dalam konteks yang hakiki setidaknya dihadapkan pada penanaman nilai-nilai bagaimana manusia mampu melakukan kontemplasi terhadap Tuhannya (vertical dimensionality) dan melakukan relasi kepada sesama manusia (horizontal dimensionality). ${ }^{1} \mathrm{Hal}$ ini berbanding lurus dengan Firman Allah SWT dalam AlQur'an yang berbunyi :

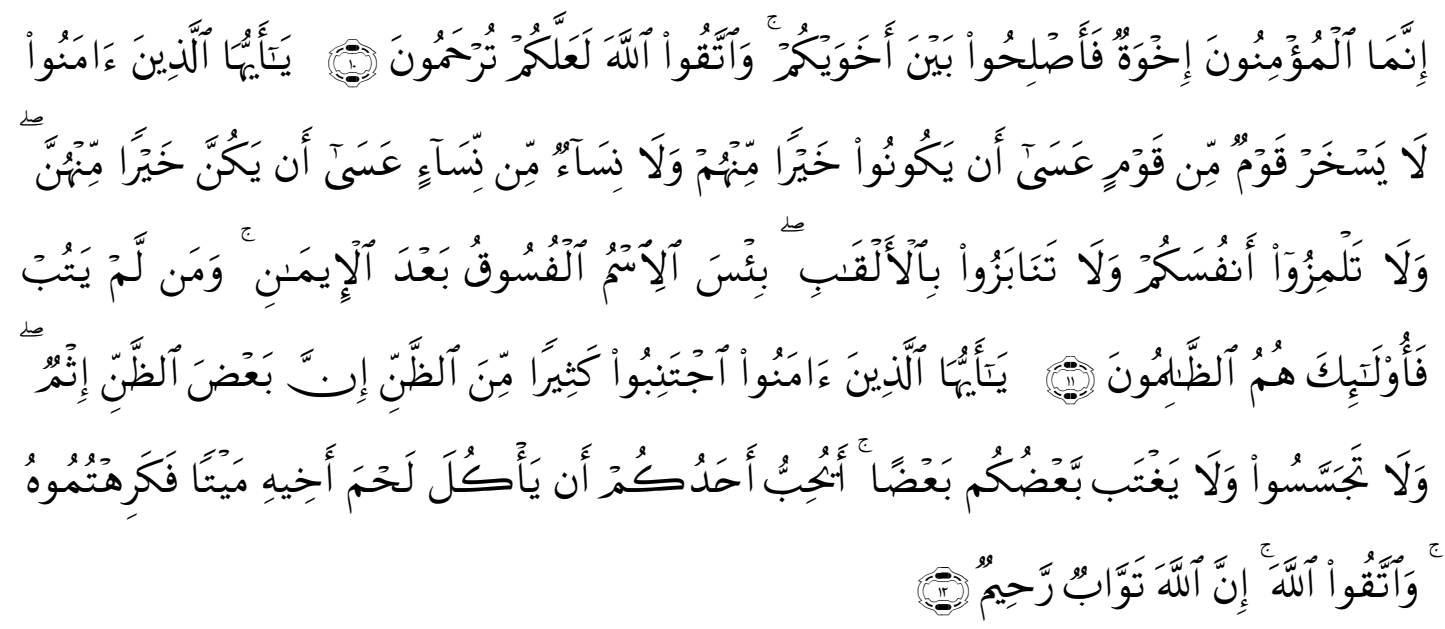

Artinya : Orang-orang beriman itu Sesungguhnya bersaudara. sebab itu damaikanlah (perbaikilah hubungan) antara kedua saudaramu itu dan takutlah terhadap Allah, supaya kamu mendapat rahmat. Hai orangorang yang beriman, janganlah sekumpulan orang laki-laki merendahkan kumpulan yang lain, boleh Jadi yang ditertawakan itu lebih baik dari mereka. dan jangan pula sekumpulan perempuan merendahkan kumpulan lainnya, boleh Jadi yang direndahkan itu lebih baik. dan janganlah suka mencela dirimu sendiridan jangan memanggil dengan gelaran yang mengandung ejekan. seburuk-buruk panggilan adalah (panggilan) yang buruk sesudah imandan Barangsiapa yang tidak bertobat, Maka mereka Itulah orang-orang yang zalim. Hai

\footnotetext{
${ }^{1}$ Harun Nasution menyatakan bahwa dimensi Islam tentang hubungan antar manusia merupakan hal yang sangat krusial. Oleh karena itu, Islam mengajarkan konsep-konsep mengenai kedudukan hak dan kewajian, serta tanggung jawab manusia. Apa yang dilakukan oleh manusia bukan saja mempunyai nilai konsekuensi di dunia, namun juga sekaligus di akhirat kelak. Lihat: Harun Nasution, Islam Rasional, Gagasan dan Pemikiran, (Bandung: Mizan, 1995), hlm 167
} 
orang-orang yang beriman, jauhilah kebanyakan purba-sangka (kecurigaan), karena sebagian dari purba-sangka itu dosa. dan janganlah mencari-cari keburukan orang dan janganlah menggunjingkan satu sama lain. Adakah seorang diantara kamu yang suka memakan daging saudaranya yang sudah mati? Maka tentulah kamu merasa jijik kepadanya. dan bertakwalah kepada Allah. Sesungguhnya Allah Maha Penerima taubat lagi Maha Penyayang (QS. Al-Hujarat:10-12).

Esensi makna kandungan ayat di atas mengisyaratkan bahwa, Islam tidak hanya sekedar sebagai sebuah agama dan sitem keyakinan yang hanya mengatur hubungan manusia dengan Tuhannya, Islam tidak hanya suatu ajaran yang bersifat dogmatis semata, namun di sisi lain Islam merupakan agama yang mengatur hubungan manusia dengan sesamnya, dan lingkungan alam sekitarnya. Dengan demikian, secara garis besar Islam merupakan suatu sistem kehidupan yang bersifat universal dalam tatanan sosial kemanusian. AlQur'an sebagai kitab suci dan pedoman dalam Islam, merupakan aspek riil yang menunjukkan universalitas Islam sebagai sistem kehidupan dalam konteks kemanusian. Perhatian Al-Qur'an dalam konteks kemanusiaan utamanya dalam hal pemberdayaan Yatim. Al-Qur'an memberikan perhatian yang khusus terhadap keberadaan Yatim dalam konteks pemberdayaan dan kemanusiaan baik secara tersurat maupun secara tersirat tersebar pada 23 ayat, baik dalam surat makiyyah maupun madaniyyah. Ayat tentang anak yatim yang termasuk surat makiyyah ada 8 ayat sedangkan yang termasuk surat madaniyyah ada 15 ayat yang terdapat dalam 5 surat. ${ }^{2}$ Perhatian Islam dengan Al-Qur'annya tentang Yatim bukan saja di dunia, melainkan juga di akhirat nanti. Kepedulian terhadap mereka dalam ajaran Islam berkaitan erat dengan masalah keimanan, ketakwaan, dan kemanusiaan. Artinya, dalam kepedulian kepada mereka harus didasari oleh keikhlasan, iman dan takwa, serta mengharap ridha Allah, di samping karena alasan kemanusiaan. Islam tidak mengajarkan untuk memberikan kepedulian kepada kaum dhuafa dengan disertai iming-iming secara halus atau terang terangan untuk menguasai apalagi mengubah keyakinan agama yang mereka anut, dan bahkan bagi mereka para yatim yang menganut agama lain selain Islam, akan tetap

${ }^{2}$ Abd. Al-Hayy al-Farmawi, Al-Bidayah Fi al-Tafsir al-Maudu'i, diterjemahkan oleh Suryan A. Jamrah, (Bandung: Bulan Bintang, 1424 H), hlm 61. 
mendapatkan perlindungan Islam yang memberi mereka ketenangan dan kedamaian. ${ }^{3}$

Pemberdayaan Yatim sebagai amanat agama dan juga aspek kemanusiaan dapat dilakukan oleh institusi pemerintah dan atau masyarakat (swasta) dalam tataran implementatif. Pemberdayaan Yatim secara manefesh terwujud dalam bentuk panti asuhan. Panti asuhan adalah suatu lembaga pelayanan sosial yang didirikan oleh pemerintah maupun masyarakat dan atau pihak swasta, yang bertujuan untuk membantu atau memberikan bantuan terhadap individu dan atau perseorangan, serta kelompok masyarakat dalam rangka memenuhi kebutuhan hidup baik secara material, mental, dan atau psikis. ${ }^{4}$ Panti Asuhan merupakan suatu lembaga usaha kesejahteraan sosial yang mempunyai tanggung jawab dalam memberikan pelayanan kesejahteraan sosial pada anak terlantar dengan melaksanakan penyantunan dan pengentasan anak terlantar, Yatim, dan Piatu dalam rangka memberikan pelayanan pengganti orang tua dan atau wali anak dalam memenuhi kebutuhan fisik, mental, dan sosial kepada anak asuh sehingga memperoleh kesempatan yang luas, tepat, dan memadai bagi pengembangan kepribadiannya sesuai dengan yang diharapkan sebagai bagian dari generasi penerus cita-cita bangsa dan sebagai insan yang akan turut serta aktif dalam bidang pembangunan nasional. Departemen Sosial Republik Indonesia menyatakan bahwa Panti asuhan secara operasional dihadapkan pada beberapa tujuan penting yaitu Pertama, Panti Asuhan memberikan pelayanan yang berdasarkan pada profesi pekerja sosial kepada anak terlantar dengan cara membantu dan membimbing mereka ke arah perkembangan pribadi yang wajar serta mempunyai keterampilan kerja, sehingga mereka menjadi anggota masyarakat yang dapat hidup layak dan penuh tanggung jawab, baik terhadap dirinya, keluarga, dan masyarakat. Kedua, Tujuan penyelenggaraan pelayanan kesejahteraan sosial anak di panti asuhan adalah terbentuknya manusiamanusia yang berkepribadian matang dan berdedikasi, mempunyai keterampilan kerja yang mampu menopang hidupnya dan hidup keluarganya. ${ }^{5}$

\footnotetext{
${ }^{3}$ Muhsin, Mari Mencintai Anak Yatim, (Jakarta: Gema Insani, 2003), hlm 55.

${ }^{4}$ Rahyudi Ruwiyanto, Peranan Pendidikan Dalam Pengentasan Masyarakat Miskin, (Jakarta: Raja Grafindo Persada, 1994), hlm 5.

${ }^{5}$ Dinas Sosial Provinsi Jawa Timur, Pedoman Pembinaan Anak Terlantar, (Surabaya: Konsorsium Dinas Sosial Provinsi Jawa Timur, 2001), hlm 8.
} 
Panti asuhan sebagai lembaga legal formal penanganan masalah sosial bagi anak terlantar, Yatim, Piatu, dan Dhuafa' tentunya mempunyai program kerja, dimana Yaim, Piatu, Dhuafa', dan anak terlantar mendapatkan pembinaan ketaqwaan terhadap Tuhan Yang Maha Esa dan pembinaan budi pekerti luhur. Tidak dapat dipungkiri bahwa anak sejak dini membutuhkan pembinaan-pembinaan tersebut, agar sikap dan perilaku nantinya tidak terseret arus yang menyesatkan perbuatan anak. Salah satu bentuk pembinaan mental agama dan kepribadian tersebut adalah pembinaan akhlak dan budi pekerti, diharapkan agar setelah keluar dari panti mereka menjadi anggota masyarakat yang berakhlak mulia, mampu hidup layak, serba teratur, tertib, disiplin serta mematuhi segala norma atau kaidah yang berlaku dalam masyarakat sehingga dapat melaksanakan fungsi sosialnya dengan wajar di tengah kehidupan sosial kemasyarakatan.

\section{Pembahasan}

\section{Metode Penelitian}

Penelitian ini termasuk dalam penelitian lapangan (field research) dan tidak dimaksudkan untuk melakukan pengujian statistik termasuk persoalan persoalan yang dirumuskan, tetapi hanyalah memberikan gambaran yang mendalam tentang permasalahan sesuai dengan data dan informasi dari lapangan melaui informan menurut interpretasi atau tafsiran dari peneliti. Pendekatan dalam penelitian ini adalah pendekatan kualitatif 6 dengan menggunakan metode survey. ${ }^{7}$ Sesuai dengan sifat penelitian kualitatif, maka

\footnotetext{
${ }^{6}$ Penelitian kualitatif sering disebut metode penelitian naturalistik karena penelitiannya dilakukan pada kondisi yang alamiah, disebut juga sebagai metode etnografi. Penelitian kualitatif dilakukan pada objek alamiah yang berkembang apa adanya, tidak dimanipulasi oleh peneliti dan kehadiran peneliti tidak begitu mempengaruhi dinamika pada objek tersebut. Penelitian kualitatif merupakan metode penelitian yang berlandaskan pada filsafat positivisme, digunakan untuk meneliti pada kondisi obyek yang alamiah, (sebagai lawannya adalah eksperimen) dimana peneliti adalah sebagai instrumen kunci, pengambilan sampel sumber data dilakukan secara purposive dan snowbaal, teknik pengumpulan dengan trianggulasi, analisis data bersifat induktif/kualitatif, dan hasil penelitian kualitatif lebih menekan makna dari pada generalisasi. Lihat: Sugiyono, Metode penelitian kuantitatif, kualitaf, dan $R \& D$, (Bandung: Alfabeta, 2011), hlm 15 .

${ }^{7}$ Metode survey yang dimaksud dalam penelitian ini berhubungan dengan prosedur pengumpulan data yang digunakan oleh peneliti dalam proses penelitian. Prosedur pengumpulan data yang digunakan dalam penelitian ini yaitu Pertama,Observasi, dalam hal ini dilakukan secara langsung selama proses penelitian di lokasi penelitian. Data yang diperoleh dengan pengamatan langsung dicatat pada catatan lapangan dengan format observasi yang telah disusun sebelumnya. Selain itu guna mendukung dan menambah bukti dari sumber-sumber informasi lain yang didapat pada hasil observasi langsung dalam hal ini peneliti juga melakukan proses dokumenter terkait dengan masalah dalam penelitian ini; Kedua, Wawancara (interview), dalam hal ini dilakukan dengan cara indepth interview. Cara ini dimaksudkan
} 
desain penelitian ini bersifat fleksibel sewaktu-waktu dapat berubah sesuai dengan kondisi dan temuan data lapangan, serta informasi yang diperoleh dari informan, sehingga desain ini bersifat sementara, menyesuaikan, dan berkembang sesuai dengan situasi, kondisi, serta temuan-temuan di lapangan. 8

Penelitian dilakukan sebagai usaha yang sistematis untuk mengungkap makna tentang "Pemberdayaan Yatim Berdasarkan Nilai-Nilai Al-Qur'an Dalam Pengelolaan Panti Asuhan Pimpinan Daerah Muhammadiyah Kabupaten Pamekasan". Dengan kata lain, secara subtantif penelitian ini ditujukan untuk menggali berbagai informasi guna untuk memahami pengalaman hidup manusia dan atau melakukan proses interpretasi makna dari subjeck dan atau objek yang diteliti, menangkap dan memahami hakikat kesadaran dan pengalaman yang berbasis pada ingatan, gambaran dan pola makna. ${ }^{9}$

Guna untuk kepentingan analisis data, dalam penelitian ini menggunakan model interaktif analisis data dengan rentetan analisis yaitu Reduksi data;10 Penyajian data; ${ }^{11}$ Penarikan kesimpulan dan atau verifikasi ${ }^{12}$

untuk menggali pendapat informan secara mendalam tentang pandangan dan pemahaman . Tujuan dari wawancara ini adalah menemukan permasalahan secara lebih terbuka, dimana pihak yang diajak wawancara dimintai pendapat dan ide-idenya. Dalam melakukan wawancara (interview) peneliti perlu mendengar secara teliti dan mencatat apa yang dikemukakan oleh subjeck atau informan; Ketiga, Dokumentasi, dalam hal ini dilakukan dengan cara mengumpulkan catatan-catatan tertulis yang berhubungan dengan masalah dan objek penelitian. Lihat: Sugiyono, Metode penelitian kuantitatif, kualitaf, dan $R \&$ D. Ibid. hlm 145.

${ }^{8}$ Lisa Harrison, Metodologi Penelitian Politik, terjemah Tri Wibowo B.S, (Jakarta: Prenada Media Group, 2007), hlm 94.

${ }_{9}^{9}$ Imam Gunawan, Metode Penelitian Kualitatif, Teori dan Praktik, (Jakarta: Bumi Aksara, 2013). hlm 56.

${ }^{10}$ Reduksi data adalah analisis data dimana Data yang diperoleh dari lapangan atau lokasi penelitian dituangkan dalam uraian dan laporan yang lengkap dan terinci. Kemudian laporan tersebut direduksi, dirangkum dan dipilih hal-hal yang penting kemudian dicari tema dan polanya. Reduksi data ini berlangsung secara terus menerus selama pelaksanaan penelitian berlangsung. Pada waktu pengumpulan data dilakukan tahap reduksi data, kemudian meringkas, mengkode, menelusuri tema, membuat gugus-gugus dan menulis memorandum teoritis. Lihat: Lexy J Moleong, Metodologi penelitian kualitatif, Edisi Revisi (Bandung: Remaja Rosdakarya, 2011). hlm 330.

${ }^{11}$ Penyajian data (display date) dimaksudkan agar memudahkan peneliti melihat gambaran secara keseluruhan atau bagian-bagian tertentu dari penelitian. Oleh karena itu dalam penelitian ini, disajikan data dalam bentuk peta dan uraian naratif. Lihat: Lexy J Moleong, Metodologi penelitian kualitatif. Ibid. hlm 330 .

${ }^{12}$ Penarikan kesimpulan dan atau Verifikasi data dalam penelitian kualitatif dilakukan secara terus menerus selama pelaksanaan peneltian. Sejak awal memasuki lapangan dan selama proses pengumpulan data, peneliti berusaha menganalisis dan mencari makna dari data yang dikumpulkan yaitu mencari pola, tema, hubungan persamaan, hal-hal yang sering timbul, hipotesis dan sebagainya yang dituangkan dalam kesimpulan yang bersifat tentatif, bila terjadi penambahan data melalui proses verifikasi secara terus menerus, barulah ditarik kesimpulan yang bersifat grounded. Dengan kata lain setiap kesimpulan senantiasa dilakukan verifikasi selama penelitian berlangsung. Dalam proses penarikan kesimpulan/verifikasi itu digunakan komponen-komponen khususnya yang berkaitan dengan temuan data 
Pengujian keabsahan data dilakukan dengan menggunakan model triangulasi. ${ }^{13}$ Teknik triangulasi digunakan sebagai pemeriksaan data yang memanfaatkan sesuatu yang lain dalam membandingkan hasil wawancara terhadap objek penelitian. Kegunaan lain teknik triangulasi ini juga biviesa memperkaya data serta untuk menyelidiki validitas tafsiran peneliti terhadap data, maka dari itu teknik triangulasi bersifat reflektif. ${ }^{14}$ Triangulasi dalam penelitian ini adalah triangulasi sumber data, Triangulasi ini dapat dilakukan dengan cara membandingkan data hasil pengamatan dengan data hasil wawancara (interview), dan selanjutnya membandingkan hasil wawancara (interview) atau observasi dengan isi suatu dokumen yang berkaitan.

\section{Hasil Penelitian}

Muhammadiyah sebagai organisasi terbesar dan tertua selain setelah Syarikat Islam (SI) berdiri pada tanggal 8 Dzulhijjah 1330 Hijriyah bertepatan dengan 18 November 1912 Masehi yang didirikan oleh KH. Ahmad Dahlan. ${ }^{15}$

di lapangan atau di lokasi penelitian. Lihat: Lexy J Moleong, Metodologi penelitian kualitatif.Iibid. hlm 330 .

13 Triangulasi adalah teknik pengujian keabsahan data yang memanfaatkan sesuatu yang lain. Triangulasi dengan sumber berarti membandingkan dan mengecek balik derajat kepercayaan suatu informasi yang diperoleh melalui waktu dan alat yang berbeda dalam penelitian kualitatif. Lihat: Lexy J Moleong, Metodologi penelitian kualitatif, Ibid. hlm 330. hlm 218

${ }^{14}$ Imam Gunawan, Metode Penelitian Kualitatif Teori \& Praktik. (Jakarta; Bumi Aksara, 2014),

${ }^{15}$ KH. Ahmad Dahlan merupakan salah satu tokoh Pemurni Islam di Indonesia. KH. Ahmad Dahlan lahir di Kauman Yogyakarta pada tahun 1869. KH. Ahmad Dahlan lahir dan tumbuh dalam latar sosial Kauman. KH. Ahmad Dahlan merupakan putra dari KH. Abu Bakar bin Kiai Sulaiman, seorang khatib tetap di Masjid Agung. Ketika lahir KH. Abu Bakar memberi nama putranya Muhammad Darwis yang kemudian diganti menjadi Ahmad Dahlan sepulangnya melaksanakan ibadah Haji. Muhammad Darwis merupakan anak keempat dari tujuh bersaudara. Ibunda Muhammad Darwis adalah Siti Aminah binti KH. Ibrahim penghulu besar di Yogyakarta. Dalam silsilah Muhammad Darwis merupakan keturunan ke-12 dari Maulana Malik Ibrahim,seorang wali terkemuka diantara Wali Songo yang merupakan pelopor dalam penyebaran dan pengembangan Islam di Tanah Jawa. Adapun Silsilah Nasab KH. Ahmad Dahlan (Pendiri Muhammadiyah) yaitu, (1) Nabi Muhammad SAW; (2) Fatimah Az-Zahra; (3) Al-Husain putera Ali bin Abu Tholib dan Fatimah Az-Zahra binti Rasulullah Muhammad SAW; (3) Al-Imam Hussain; (4) Ali Zainal Abidin; (5) Muhammad Al Baqir; (6) Ja'far As-Sodiq; (7) Al-Imam Ali Uradhi; (8) Muhammad An-Naqib; (9) Isa Naqib Ar-Rumi; (10) Ahmad Al-Muhajir; (11) Al-Imam Ubaidillah; (12) Alawi Awwal; (13) Muhammad Sohibus Saumi'ah; (13) Alawi Ats-Tsani; (14) Ali Kholi' Qosim; (15) Muhammad Sohib Mirbath (Hadhramaut); (16) Alawi Ammil Faqih (Hadhramaut); (17) Amir Abdul Malik Al-Muhajir (Nasrabad, India); (18) Abdullah Al-Azhomatu Khan; (19) Ahmad Shah Jalal (Ahmad Jalaludin Al-Khan); (20) Syaikh Jumadil Qubro (Jamaluddin Akbar Al-Khan); (21) Maulana Malik Ibrahim Asmoroqandi (Syech Samsu Tamres); (22) Adipati Andayaningrat (Kiyai Ageng Penging Sepuh / Syarif Muhammad Kebungsuan II); (23) Kiyai Ageng Kebo Kanigoro bergelar Kiyai Ageng Banyu Biru bergelar Kiyai Ageng Gribig I bergelar Sunan Geseng; (24) Ki Ageng Gribig II; (25) Ki Ageng Gribig III (Kiyai Getayu); (25) Ki Ageng Gribig IV; (26) Ki Demang Juru Sapisan; (27) Ki Demang Juru Kapindo; (28) Kiyai Ilyas; (29) Kiyai Murthada; (30) KH. Muhammad Sulaiman; (31) KH. Abu Bakar; (32) KH. Ahmad Dahlan (Muhammad Darwis) Pendiri Muhammadiyah. Lihat: Adi Nugroho, Biografi Singkat KH. Ahmad Dahlan, (Yogyakarta: Garasi, 2015), hlm 11. 
Persyarikatan Muhammadiyah merupakan organisasi yang dalam pendiriannya sebagai tempat berkumpulnya ummat Islam yang merupakan pengikut Nabi Muhammad SAW dengan berlandaskan Al-Qur'an dan AlHadist dalam mengaktualisasikan nilai-nilai ajaran Islam dalam konteks sosial kemasyarakatan. ${ }^{16}$

Dalam kurun waktu menjelang tahun 1920 gerakan Muhammadiyah mulai meluas keluar wilayah Yogyakarta. Beberapa daerah di Jawa mulai tertarik terhadap gerakan Muhammadiyah dan berniat untuk mendirikan cabang-cabang di wilayahnya. Proses pelaksanaan pembentukan cabangcabang di daerah-daerah diluar Yogyakarta berjalan dengan lancar, dimana dalam tahun yang sama yaitu tahun 1920 Muhammadiyah menambahkan dalam anggaran dasarnya tentang perluasan Muhammadiyah untuk daerah-daerah diseluruh Jawa, dan pada tahun 1921 anggaran itu diperbaharui lagi untuk tujuan perluasan kegiatan dakwah Muhammadiyah diseluruh wilayah Indonesia. Sebagai organisasi gerakan, Persyarikatan Muhammadiyah mempunyai beberapa majelis diantaranya adalah Majelis Tarjih, yang bertugas menentukan hukum-hukum Islam yang akan menjadi pedoman masyarakat sesuai denagn Al-Qur'an dan Hadist; Majelis Tabligh yang mempunyai tugas berdakwah yaitu menyebarkan agama Islam baik kepada umat Islam sendiri supaya tetap pada pelajaran Islam yang murni, maupun kepada umat yang belum beragama supaya memeluk agama Islam. Dalam bidang pendidikan terdapat Majelis Pendidikan Pengajaran, yang bertugas memajukan pendidikan, pengajaran dan kebudayaan serta memperluas ilmu pengetahuan menurut tuntunan agama Islam; Majelis Ekonomi, yang bertugas membimbing kearah perbaikan kehidupan dan penghidupan ekonomi anggota, keluarga dan masyarakat, Majelis Wakaf dan Kehartabendaan bertugas memelihara tempat-tempat ibadah dan mengurus masalah tanah dan hak milik Muhammadiyah lainnya. Majelis yang juga cukup penting adalah Majelis Pembina kesejahteraan umat, yang bertugas menggerakkan amal tolongmenolong, merawat orang sakit, membantu orang miskin, mengurusi kematian dan mengurusi anak-anak yatim. ${ }^{17}$

\footnotetext{
${ }^{16}$ Achmadi, Merajut Pemikiran Cerdas Muhammadiyah Perspektif Sejarah, (Yogyakarta: Suara Muhammadiyah, 2010), hlm 1.

${ }^{17}$ Mustafa Kamal Pasha, Muhammadiyah Sebagai Gerakan Islam, (Yogyakarta: Persatuan, 1970), hlm 7.
} 
Persyarikatan Muhammadiyah dalam perkembangannya mampu mendirikan berbagai amal usaha yang bergerak dalam bidang pendidikan dan pengajaran, kesejahteraan dan kesehatan masyarakat, dan pembinaan kehidupan beragama Islam. ${ }^{18}$ Sebagai organisasi gerakan, sosial, dan dakwah Persyarikatan Muhammadiyah memiliki Panti Asuhan yang sampai saat ini menjadi ciri khas dalam pengelolaan Amal usaha milik Muhammadiyah (AUM) sebagai refleksi terhadap nilai-nilai Al-Ma'un ${ }^{19}$ (الماعؤن). Keberadaan Panti Asuhan milik Muhammadiyah tidak terlepas dari pembentukan suatu badan dalam tubuh Persyarikatan Muhammadiyah yang diberi nama Penolong Kesengsaraan Oemoem (PKO) yang dibentuk pertama kali pada tahun 1915 yang tugas dalam pengelolaan lembaga-lembaga sosial milik Muhammadiyah yang tercakup dididalamnya salahsatunya adalah penampungan dan penyantunan terhadap anak yatim dan terlantar. Majelis Penolong Kesengsaraan Oemoem (PKO) itu sendiri pada pertama kalinya merealisasikan ide dengan mendirikan rumah yatim piatu di Yogyakarta pada tahun 1922 yang dipimpin oleh Dokter Somawidagdo. ${ }^{21}$

Seiring dengan berjalannya waktu, Rumah Sakit milik Muhammadiyah dibawah Majelis Penolong Kesengsaraan Oemoem (PKO) resmi didirikan pada tahun 1923 yang diprakarsai Soeroharsojo, yang selanjutnya pada tahun 1930 Majelis Penolong Kesengsaraan Oemoem (PKO) menambah amal usaha dengan mendirikan Panti asuhan keluarga yatim Muhammadiyah (PAKYM) yang diprakarsai oleh KH. Muhammad Edris Abdussalam, yang pada saat itu menjadi pemuka muda Muhammadiyah, dengan nama Rumah Miskin Muhammadiyah. Pendirian Rumah Miskin Muhammadiyah ini berdasarkan Akte Pendirian Persyarikatan Muhammadiyah sebagai badan hukum dengan

${ }^{18}$ MT. Arifin, Gagasan Pembaharuan Muhammadiyah, (Jakarta: Pustaka Jaya, 1987), hlm 242.

${ }^{19}$ Nilai-nilai Al-Maa'un ( الماعؤن ) merupakan entitas dalam Al-Qur'an yang dijadikan landasan ideologis dan falsafah dalam kerangka pengembangan dan pengembangan organisasi gerakan perjuangan Muhammadiyah sejak KH. Ahmad Dahlan periode pertama pendirian, sampai saat ini. Lihat: Susianti Br Sitepu, Pemikiran Teologi KH. Ahmad Dahlan, (Sumatera: Jurnal Al-Lubb, Vol. 2, No. 1, 2017), hlm 148.

${ }^{20}$ Banyak perbedaan dalam kitab-kitab tafsir dalam menyebut nama surat ini, ada yang menyebut nama surat ini dengan sebutan الماعؤن dan sebagian tafsir menyebutnya dengan sebutan الديت ada yang mengatakan surat الدين ada yang menyatakan surat اليتيم, Lihat: 50Muhammad at Thahir Ibnu Asyur, Tafsir al Tahrir wa al Tanwir, (Tunisia: Daar Sahnun li al Nasar wa al Tauzi', t.t), 563. Namun lebih banyak memberi nama dengan Surat الماعؤن seperti Imam Baghawi, Imam Abu Su'ud, Imam al Qurthubi, Imam al Halabi, Imam al Khazin, Imam As-Suyuthi, Imam At-Thabarsi dan juga Imam Abu Thahir al Fairuzzabadi. Lihat: Abi Ja'far Muhammad bin Jarir at Thobari, Jaami' al Bayan an Ta'wil Ayi AlQur'an (Beirut: Dar Al Fikr, 1995), Juz 30, hlm 405.

${ }^{21}$ Deliar Noor, Gerakan Modern Islam di Indonesia 1900-1942, (Jakarta: LPE3S, 1990), hlm 90. 
Nomor: 81/byl. 1. sebagai dasar hukum dalam penyelenggaraannya, yang dalam perkembangannya seiring dengan bergulirnya kebijakan Pemerintah pada tahun 1956 Rumah Miskin Muhammadiyah ini berganti nama menjadi Panti Asuhan Yatim Muhammadiyah (PAYM) berdasarkan surat keputusan menteri sosial RI tertanggal 8 Nopember 1955, No. sekr. 10-22-17/1895 yang telah pula mendapat persetujuan dari pimpinan pusat Muhammadiyah Majelis PKU Daerah Surakarta yang termaktup dalam suratnya tanggal 5 Januari 1956 No. 014/56, dan penggunaan nama ini dimulai pelaksanannya pada tahun 1956. Dalam tahun yang sama tahun 1956 sebagai kelanjutan dari adanya rumah darurat yang dibangun oleh pengurus $\mathrm{PKO}$, rupanya menarik perhatian pemerintah Kota Madia Surakarta yang memberi bantuan sebidang tanah kepada Muhammadiyah Daerah Surakarta seluas 1,5 На. ${ }^{22}$

Pembabakan dan kronologis tentang sejarah pendirian dan kehadiran Panti asuhan Muhammadiyah ditengah dalam rangka melakukan proses pendampingan dan pemberdayaan bagi masyarakat, utamanya dalam pemberdayaan Yatim tentunya juga berbanding lurus dengan keberadaan Panti Asuhan Muhammadiyah Kabupaten Pamekasan. Secara organisastoris, pengelolaan Panti Asuhan Muhammadiyah Kabupaten Pamekasan berada dibawah Pimpinan Daerah Muhammadiyah Kabupaten Pamekasan, yang merupakan salahsatu dari 6 (enam) Organisasi Islam di Kabupaten Pamekasan yang dikenal dengan Kabupaten Bumi Gerbangsalam (Gerakan Pembangunan Masyarakat Islami). ${ }^{23}$

${ }^{22}$ Tim Pembina Panti Asuhan Keluarga Yatim Muhammadiyah Bekerjasama dengan Universitas Muhammadiyah Surakarta (UMS), Panti Asuhan Keluarga Yatim Muhammadiyah Surakarta, (Surakarta: 1997), hlm 2.

${ }^{23}$ Gerakan pembangunan masyarakat Islami (Gerbang Salam) merupakan adalah produk kebijakan berdasarkan Bupati Pamekasan Nomor 188/126/441.012/2002, Tanggal 30 April 2002, jo Surat keputusan Bupati Pamekasan nomor 188/340/44.131/2009, Tanggal, 19 Oktober 2009, tentang penetapan Kabupaten Pamekasan sebagai Kabupaten Gerakan pembangunan masyarakat Islami (Gerbangsalam) sebagai model dan strategi dakwah di Kabupaten Pamekasan. Secara subtantif Gerakan pembangunan masyarakat Islami (Gerbang salam) adalah upaya bersama yang dilakukan secara sistematis dan terus menerus dalam rangka mentransformasi nilai-nilai ajaran Islam dalam kehidupan sehari-hari. Kebijakan ini dilatarbelakangi dengan beberapa faktor Pertama, Kewajiban untuk menjalankan syari'at Islam secara kaffah; Kedua, Momentum reformasi yang membuka peluang untuk memasukkan nilai-nilai ajaran Islam dalam rumusan kebijakan di era otonomi daerah; Ketiga, Lahirnya peraturan daerah tentang larangan minuman beralkohol; Keempat, Adanya seminar-seminar dan bahsun masail tentang pentingnya penerapan hukum/Syari'at Islam sebagai forum yang menghimpun keinginan sebagian besar masyarakat Kabupaten Pamekasan sebagai satu dari empat Kabupaten di wilayah arel Pulau Garam yang berpenduduk mayoritas muslim. Tujuan dari Gerbang Salam untuk mewujudkan motto kabupaten Pamekasan yaitu "Mekkas Jatnah Paksa Jenneng Dibi" yang artinya ingatlah selalu pesan nenek moyang agar selalu hati-hati atau teliti serta tidak mudah terpengaruh orang lain dan harus sanggup berdiri diatas kekuatan diri sendiri dalam mengatur pemerintahan yang dapat menciptakan kesejahteraan, kemakmuran dan keadilan bagi 
Pemberdayaan Yatim dalam Pengelolaan Panti Asuhan Pimpinan daerah Muhammadiyah Kabupaten Pamekasan, selain harus tunduk pada AD/ART dan peraturan perundang-undangan yang berlaku, yang tidak kalah pentingnya, bagaimana dalam pemberdyaan Yatim harus senantiasa berpegang teguh pada nilai-nilai Al-Qur'an sebagai fondamen dasar dalam kerangka pengelolaan Panti Asuhan Pimpinan daerah Muhammadiyah Kabupaten Pamekasan.

Hasil penelitian tentang "Pemberdayaan Yatim Berdasarkan Nilai-Nilai Al-Qur'an Dalam Pengelolaan Panti Asuhan Pimpinan Daerah Muhammadiyah Kabupaten Pamekasan" menunjukkan beberapa pola makna yang bersifat interpretatif sebagaimana berikut :

1. Pemberdayaan Yatim dalam kerangka Pengelolaan Panti Asuhan Pimpinan Daerah Muhammadiyah Kabupaten Pamekasan adalah proses pengabdian spiritualitas Keagamaan untuk menjalankan risalah AlQur'an, guna untuk memperoleh Ridla Allah SWT. Hal ini berdasarkan Firman Allah SWT dalam Al-Qur'an Sebagai berikut :

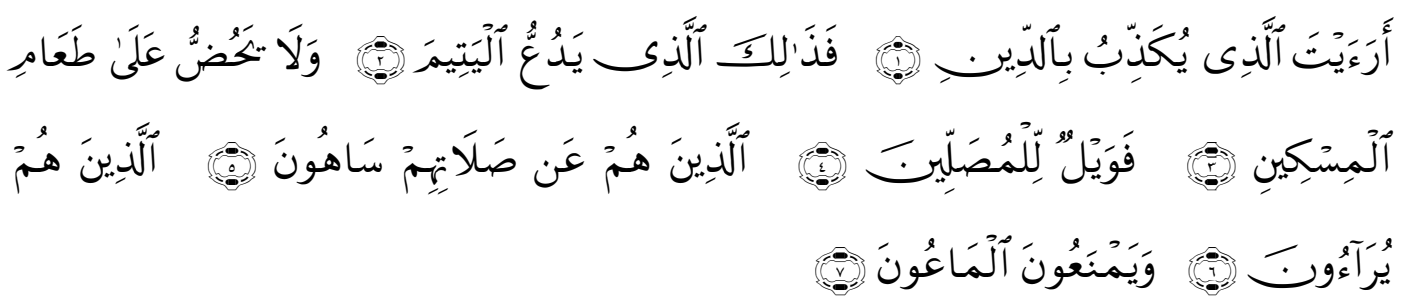

Artinya: Tahukah kamu (orang) yang mendustakan agama? itulah orang yang menghardik anak yatim, dan tidak menganjurkan memberi makan orang yang miskin, maka kecelakaanlah bagi orang - orang yang shalat, yang mereka itu lalai dari shalatnya, yang mereka itu berbuat riya, dan enggan (menolong dengan) barang berguna (QS. Al-Maa'un : 1-7).

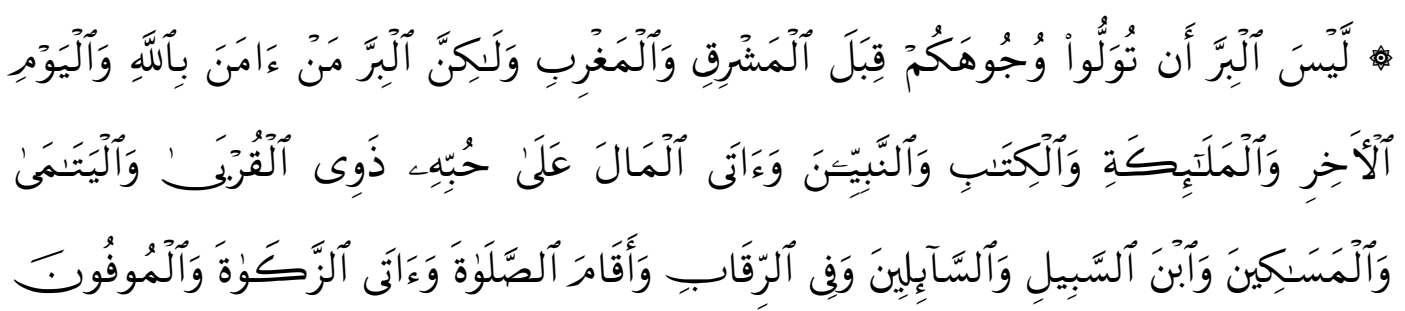

masyarakat Madura umumnya dan daerah Pamekasan pada khususnya. Lihat: Tim LP2SI, “Buku saku Gerbang Salam: Mengenal Gerbang Salam, (LP2SI Kabupaten Pamekasan, tidak diterbitkan, 2011), hlm 2. 


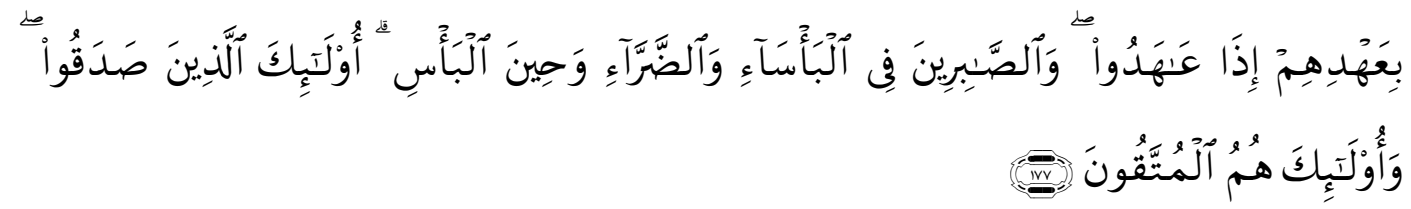

Artinya: Sesungguhnya kebajikan itu adalah beriman kepada Allah, hari kemudian, malaikat-malaikat, kitab-kitab, nabi-nabi, dan memberikan harta yang dicintinya kepada kerabatnya, anak-anak yatim. (QS. AlBaqarah 177)."

2. Pemberdayaan Yatim dalam kerangka Pengelolaan Panti Asuhan Pimpinan Daerah Muhammadiyah Kabupaten Pamekasan adalah proses pemenuhan kebutuhan kepada Yatim yang sejatinya butuh pengayoman, baik secara jasmaniyah maupun secara batiniyah. Hal ini berdasarkan Firman Allah SWT dalam Al-Qur'an sebagai berikut :

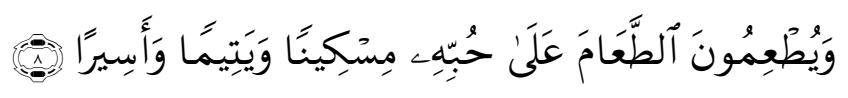

Artinya: Dan mereka memberi makanan yang disukainya kepada orang miskin dan anak-anak yatim. (QS. Al-Ihsan: 8).

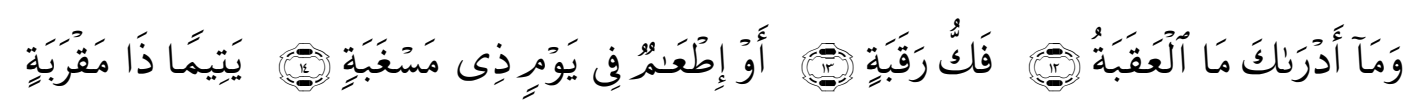

Artinya: Tahukah kamu apakah jalan yang mendaki sukar lagi sukar itu? Yaitu melepaskan budak dan perbudakan. Atau memberi makan pada hari kelaparan, kepada anak-anak yatim yang ada hubungan kerebat.(QS. AlBalad: 12-15).

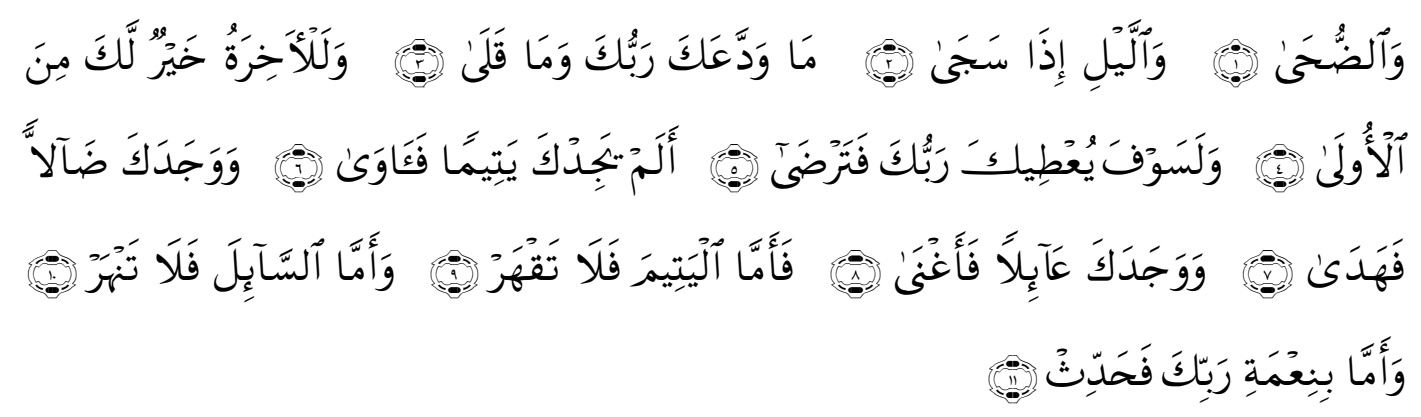

Artinya: Demi waktu matahari sepenggalahan naik, dan demi malam apabila telah sunyi (gelap), Tuhanmu tiada meninggalkan kamu dan tiada (pula) benci kepadamu. dan Sesungguhnya hari kemudian itu lebih baik bagimu 
daripada yang sekarang (permulaan). dan kelak Tuhanmu pasti memberikan karunia-Nya kepadamu, lalu (hati) kamu menjadi puas. Bukankah Dia mendapatimu sebagai seorang yatim, lalu Dia melindungimu? Dan Dia mendapatimu sebagai seorang yang bingung, lalu Dia memberikan petunjuk. Dan Dia mendapatimu sebagai seorang yang kekurangan, lalu Dia memberikan kecukupan. Sebab itu, terhadap anak yatim janganlah kamu Berlaku sewenang-wenang. Dan terhadap orang yang minta-minta, janganlah kamu menghardiknya. Dan terhadap nikmat Tuhanmu, Maka hendaklah kamu siarkan (QS. Ad-Dhuha: 1-11).

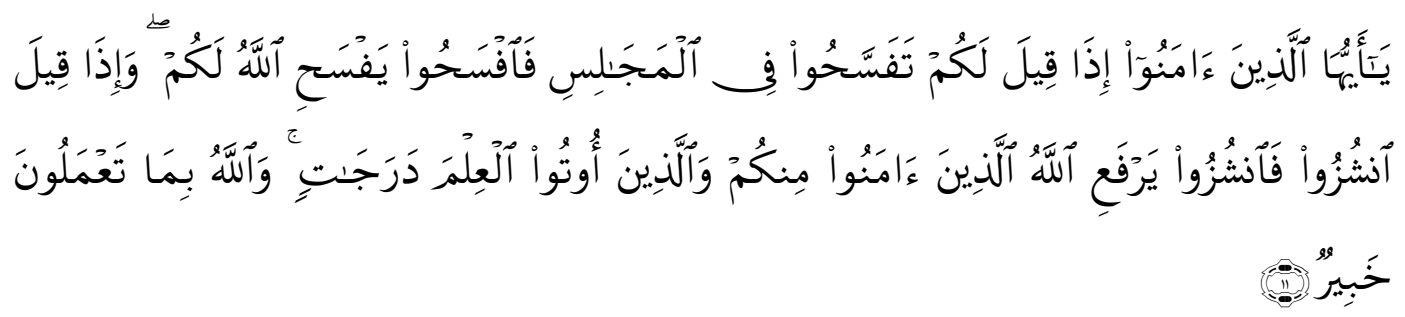

Artinya: Hai orang-orang beriman apabila kamu dikatakan kepadamu berlapanglapanglah dalam majlis, Maka lapangkanlah niscaya Allah akan memberi kelapangan untukmu. dan apabila dikatakan: Berdirilah kamu", Maka berdirilah, niscaya Allah akan meninggikan orang-orang yang beriman di antaramu dan orang-orang yang diberi ilmu pengetahuan beberapa derajat. dan Allah Maha mengetahui apa yang kamu kerjakan. (AlMujadalah: 11).

3. Pemberdayaan Yatim dalam kerangka Pengelolaan Panti Asuhan Pimpinan Daerah Muhammadiyah Kabupaten Pamekasan adalah proses penyelamatan terhadap harta Yatim yang harus diselamatkan. Hal ini berdasarkan Firman Allah SWT dalam Al-Qur'an sebagai berikut :

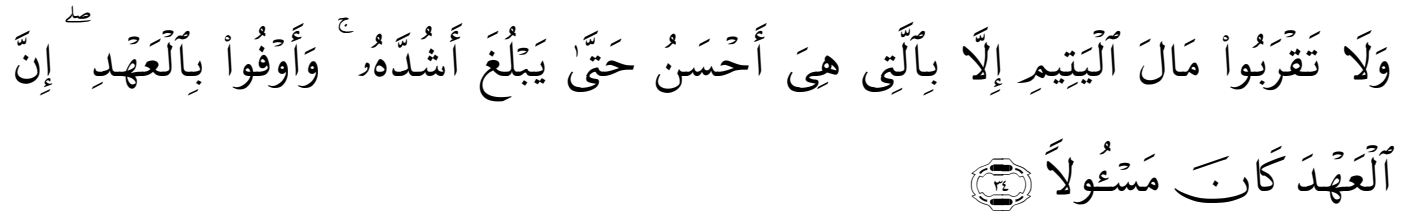

Artinya: Dan janganlah kamu mendekati harta anak yatim, kecuali dengan cara yang baik (bermanfaat) sampai dia dewasa, dan penuhilah janji itu pasti diminta pertanggungjawabannya. (Al-Isra': 34).

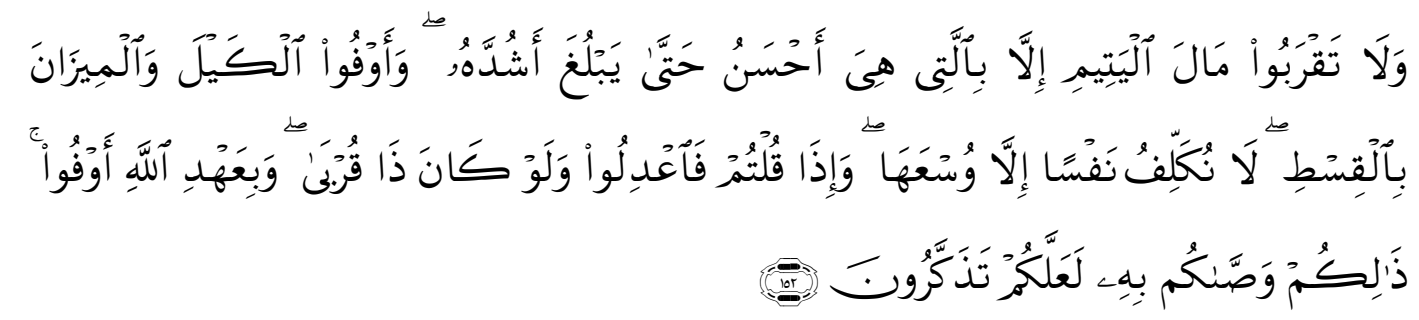


Artinya: Dan janganlah kamu dekati harta anak yatim, kecuali dengan cara yang lebih bermanfaat, hingga sampai ia dewasa. dan sempurnakanlah takaran dan timbangan dengan adil. Kami tidak memikulkan beban kepada sesorang melainkan sekedar kesanggupannya. dan apabila kamu berkata, Maka hendaklah kamu Berlaku adil, Kendatipun ia adalah kerabatmu, dan penuhilah janji Allah. yang demikian itu diperintahkan Allah kepadamu agar kamu ingat. (QS. Al-An"ām ayat 152).

Implikasi teoritik dari temuan penelitian sebagaimana disajikan di atas menunjukkan bahwa Pemberdayaan Yatim Berdasarkan Nilai-Nilai AlQur'an Dalam Pengelolaan Panti Asuhan Pimpinan Daerah Muhammadiyah Kabupaten Pamekasan searah dengan isi kandungan nilai-nilai Al-Qur'an yang berhungan dengan pemberdayaan Yatim.

\section{Penutup}

Berdasarkan hasil penelitian dan interpretasi dari temuan penelitian tentang "Pemberdayaan Yatim Berdasarkan Nilai-Nilai Al-Qur'an dalam Pengelolaan Panti Asuhan Pimpinan Daerah Muhammadiyah Kabupaten Pamekasan" dapat disimpulkan bahwa pemberdayaan Yatim merupakan suatu proses pendampingan mental dan spiritual dalam ranka memperoleh Ridla Allah SWT. Pemberdayaan Yatim dalam tataran implementatif berhubungan dengan proses pemenuhan kebutuhan Yatim baik material, sosial, dan bahkan spiritual. Pemberdayaan Yatim juga berhungan dengan proses penyelamatan terhadap harta Yatim. Proses pemberdayaan ini merupakan refleksi terhadap nilai-nilai Al-Qur'an sebagai risalah tertinggi dalam Agama Islam. 


\section{DAFTAR PUSTAKA}

Abd. Al-Hayy al-Farmawi, Al-Bidayah Fi al-Tafsir al-Maudu'i, diterjemahkan oleh Suryan A. Jamrah, Bandung, Bulan Bintang, $1424 \mathrm{H}$.

Abi Ja'far Muhammad bin Jarir at Thobari, Jaami' al Bayan an Ta'wil Ayi AlQur'an, Beirut, Dar Al Fikr, 1995.

Achmadi, Merajut Pemikiran Cerdas Muhammadiyah Perspektif Sejarah, Yogyakarta, Suara Muhammadiyah, 2010.

Adi Nugroho, Biografi Singkat K.H. Ahmad Dahlan, Yogyakarta, Garasi, 2015.

Deliar Noor, Gerakan Modern Islam di Indonesia 1900-1942, Jakarta, LPE3S, 1990.

Dinas Sosial Provinsi Jawa Timur, Pedoman Pembinaan Anak Terlantar, Surabaya, Konsorsium Dinas Sosial Provinsi Jawa Timur, 2001.

Gouvernement Besluit 22 Augustus 1914 No. 81.

Gouvernement Besluit 16 Augustus 1920 No. 40.

Gouvernement Besluit 2 September 1921 No. 36.

Harun Nasution, Islam Rasional, Gagasan dan Pemikiran, Bandung, Mizan, 1995.

Imam Gunawan, Metode Penelitian Kualitatif, Teori dan Praktik, Jakarta, Bumi Aksara, 2013.

Lexy J Moleong, Metodologi penelitian kualitatif, Edisi Revisi Bandung, Remaja Rosdakarya, 2011.

Lisa Harrison, Metodologi Penelitian Politik, terjemah Tri Wibowo B.S, Jakarta, Prenada Media Group, 2007.

Muhsin, Mari Mencintai Anak Yatim, Jakarta, Gema Insani, 2003.

Mustafa Kamal Pasha, Muhammadiyah Sebagai Gerakan Islam, Yogyakarta, Persatuan, 1970.

MT. Arifin, Gagasan Pembaharuan Muhammadiyah, Jakarta, Pustaka Jaya, 1987.

Peraturan Kepala Badan Pertanahan Nasional RI Nomor 3 Tahun 2012. 
Rahyudi Ruwiyanto, Peranan Pendidikan Dalam Pengentasan Masyarakat Miskin, Jakarta, Raja Grafindo Persada, 1994.

Sugiyono, Metode penelitian kuantitatif, kualitaf, dan $R \mathcal{E} D$, Bandung, Alfabeta, 2011.

Susianti Br Sitepu, Pemikiran Teologi KH. Ahmad Dahlan, Sumatera, Jurnal AlLubb, Vol. 2, No. 1, 2017.

Surat Keterangan dari Pemerintah Hindia Belanda tentang Rechtpersoonlijkheid Van Vereenigingen K.B. Van 28 Maart Stb. 70 - 64, Art.5a (Ingev.Stb.33-80).

Surat Penyataan Menteri Agama RI Nomor 1 Tahun 1971 tanggal 9 September 1971.

Surat Keterangan Menteri Sosial RI Nomor K/162-IK/71/MS tanggal 7 September 1971.

Surat Direktorat Jenderal Pembinaan Hukum Departemen Kehakiman RI Nomor J.A.5/160/4 tanggal 8 September 1971.

Surat Keputusan Menteri Dalam Negeri RI Nomor Sk.14/DDA/172 tanggal 10 Pebruari 1972 .

Surat Perpanjangan Keputusan Dalam Negeri RI Nomor Sk.14/DDA/1972/A/13 tanggal 27 Pebruari 1980.

Surat Pernyataan Menteri Pendidikan dan Kebudayaan RI Nomor 23628/MPK/74 tanggal 24 Juli 1974.

Surat Pernyataan Menteri Kesehatan RI Nomor 155/Yan.Med/Um/1988 tanggal 22 Pebruari 1988.

Surat Departemen Kehakiman dan Hak Asasi Manusia RI Nomor C2HT.01.03.A.165 tanggal 29 Januari 2004.

Surat Keputusan Menteri Hukum dan Hak Asasi Manusia RI Nomor AHU.88.AH.01.07 Tahun 2010 tanggal 23 Juni 2010.

Surat Bersama Badan Pertanahan Nasional RI dengan Persyarikatan Muhammadiyah tentang Percepatan Pengurusan Hak dan Penerbitan Sertifikat Tanah Persyarikatan Muhammadiyah.

Surat Nomor A/1-1077/85 tanggal 2 Sya'ban 1405 H/23 April 1985 perihal Badan Hukum Muhamamdiyah. 
Surat Nomor I-A/8.a/1588/1993 tanggal 1 Rajab 1414 H/15 Desember 13 perihal Badan Hukum.

Surat Nomor 03/Skt/I-A/8.a/2001 M tanggal 27 Shafar 1422 H/21 Mei 2001 M tentang Persyarikatan Muhamamdiyah sebagai Badan Hukum.

Surat Nomor 328/EDR/I.0/B/2005 tertanggal 10 Robiulakhir 1426 H/19 Mei 2005 M tentang Badan Hukum Muhammadiyah.

Surat Keterangan Pimpinan Pusat Muhammadiyah Nomor 01/KET/I.0/B/2013 tentang Persyarikatan Muhammadiyah Sebagai Badan Hukum.

Tim Pembina Panti Asuhan Keluarga Yatim Muhammadiyah Bekerjasama dengan Universitas Muhammadiyah Surakarta (UMS), Panti Asuhan Keluarga Yatim Muhammadiyah Surakarta, Surakarta, 1997.

Tim LP2SI, Buku saku Gerbang Salam: Mengenal Gerbang Salam, LP2SI Kabupaten Pamekasan, tidak diterbitkan, 2011. 